\title{
CD70 wt Allele
}

National Cancer Institute

\section{Source}

National Cancer Institute. CD70 wt Allele. NCI Thesaurus. Code C104078.

Human CD70 wild-type allele is located in the vicinity of $19 \mathrm{p} 13$ and is approximately $8 \mathrm{~kb}$ in length. This allele, which encodes CD70 antigen protein, plays a role in T-cell activation and proliferation. 